\title{
KONSELING MENGGUNAKAN MODUL SEBAGAI MEDIA EDUKASI TERHADAP TINGKAT KECEMASAN IBU NIFAS PADA MASA PANDEMI COVID-19
}

\author{
Febriana Sari ${ }^{1}$, Herna Rinayanti Manurung ${ }^{2}$, Evi Rosida Sihombing ${ }^{3}$ \\ ${ }^{1}$ STIKes Mitra Husada Medan \\ ${ }^{2}$ STIKes Mitra Husada Medan \\ ${ }^{3}$ STIKes Mitra Husada Medan
}

febriamoy3290@gmail.com, herna.yanti28@gmail.com, evirosida503@gmail.com

\begin{abstract}
Abstrak
Corona Virus Disease 2019 (COVID-19) adalah penyakit yang sedang mewabah hampir diseluruh penjuru dunia pada saat ini. Kebijakan program nasional dalam masa nifas dan menyusui merupakan suatu hal yang sangat penting dalam kesejahteraan ibu nifas dan bayinya seperti menilai kesehatan ibu dan bayi, melakukan pencegahan terhadap kemungkinan masalah kesehatan, mendeteksi adanya komplikasi penyakit terhadap ibu nifas dan bayinya, beberapa komponen essensial dalam asuhan kebidanan pada ibu selama masa nifas. Dampak negatif mungkin lebih besar di antara ibu nifas yang mengalami peningkatan stres karena mengkhawatirkan bayi mereka. Konseling menggunakan modul bertujuan dapat menjadi edukasi pada ibu nifas terkait kecemasannya terhadap pandemi covid-19 melalui metode konseling. Kegiatan dilaksanakan UPT Puskesmas Kecamatan Sumbul Pegagan Kabupaten Dairi Provinsi Sumatera Utara. Pada studi awal dilakukan sebelum kegiatan ditemukannya masih banyak ibu nifas mengalami kecemasan. Kecemasan yang di tunjukkan oleh ibu nifas yang diwawancarai, membutuhkan suatu cara yakni memberikan pendidikan kesehatan melalui konseling dengan media modul yang bertujuan untuk peningkatan pemahaman upaya pencegahan Covid-19 pada ibu nifas dan menyusui sehingga mengurangi kecemasan ibu nifas selama pandemi COVID-19. Dari kegiatan pengabdian masyarakat ini didapati adanya peningkatan pengetahuan dan pemahaman ibu nifas dalam upaya pencegahan dan penurunan kecemasan karena COVID-19. Selanjutnya perlu adanya pemantauan lebih lanjut atas perubahan perilaku setelah dilakukan konseling ini.
\end{abstract}

\section{Kata Kunci : COVID-19, Modul, Tingkat Kecemasan Ibu Nifas}

\section{PENDAHULUAN}

Kondisi pandemi mengharuskan masyarakat untuk selalu mematuhi protokol kesehatan. Virus yang menyebabkan COVID-19 ini berasal dari golongan virus yang sama dengan virus penyebab severe acute respiratory syndrome (SARS) dan Middle-East respiratory syndrome (MERS). Berdasarkan kejadian yang lalu, ibu hamil dengan
SARS atau MERS juga berisiko lebih tinggi mengalami keguguran atau melahirkan bayi prematur. Kejadian ini juga bisa terjadi pada ibu hamil dengan COVID-19, namun laporan kejadiannya masih sangat sedikit. Hal ini juga dapat dialami tidak hanya pada ibu hamil tetapi pada ibu nifas, menyusui bahkan sampai lansia. Langkah utama yang dapat dilakukan dalam kondisi saat ini yaitu lebih meningkatkan pengetahuan dan 
kewaspadaan baik itu tenaga medis maupun masyarakat mengenai social distancing.

Kebijakan Program Nasional dalam masa nifas dan menyusui merupakan suatu hal yang sangat penting dalam kesejahteraan ibu Nifas dan bayinya seperti menilai kesehatan ibu dan bayi,melakukan pencegahan terhadap kemungkinan masalah kesehatan,mendeteksi adanya komplikasi penyakit terhadap ibu Nifas dan bayinya,beberapa komponen essensial dalam asuhan kebidanan pada ibu selama masa Nifas yaitu,Anjurkan ibu untuk melakukan kunjungan masa Nifas sebanyak 4 kali yaitu pada periode 6 (enam) jam sampai dengan 2 (dua) hari pasca persalinan, pada periode 3 (tiga) hari sampai dengan 7 (tujuh) hari pasca persalinan, pada periode 8 (delapan) hari sampai dengan 28 (dua puluh delapan) hari pasca persalinan, pada periode 29 (dua puluh sembilan) sampai dengan 42 (empat puluh dua) hari pasca persalinan. (Kemenkes, 2020).

Kunjungan nifas kedua, ketiga dan keempat dapat dilakukan dengan metode kunjungan rumah oleh tenaga kesehatan atau pemantauan menggunakan media online (disesuaikan dengan kondisi daerah terdampak COVID-19), dengan melakukan upaya-upaya pencegahan penularan COVID-19 baik dari petugas, ibu dan keluarga (Kemenkes, 2020)

Ibu nifas yang belum berpengalaman biasanya mendapat bantuan dari suami dan ibunya dalam merawat bayi pada periode awal postpartum. Ibu nifas sangat membutuhkan dukungan dari orang di sekitarnya. Hal ini disebabkan karena dukungan sosial yang adekuat berhubungan dengan menurunnya mortalitas, lebih mudah sembuh dari sakit, fungsi kognitif, fisik dan kesehatan emosi (Setiana, 2019).

Menurut Davies (2009) kecemasan merupakan suatu keadaan emosional yang tidak menyenangkan yang ditandai dengan rasa ketakutan serta gejala fisik yang menegangkan yang tidak diinginkan. Kelahiran seorang anak menyebabkan tantangan mendasar terhadap struktur interaksi keluarga yang sudah terbentuk. Sebagian besar wanita mengalami ganngguan emosional setelah melahirkan. Bentuk gangguan postpartum yang umum adalah depresi, mudah marah dan mudah frustasi, serta emosional. Gangguan mood selama periode postpartum merupakan salah satu gangguan yang paling sering terjadi pada ibu post partum, baik primipara maupun multipara.

Kecemasan pada ibu nifas dapat memberikan pengaruh yang tidak baik untuk bayi, mental ibu dari bayi itu sendiri, serta hubungan pernikahannya. Hormon yang mengalami perubahan dalam angka yang cukup besar akan membuat suasana hati berubah yaitu seperti Hormon progesterone, estrogen, kelenjar tiroid, kortisol, dan prolaktin. Kecemasan pada ibu nifas biasanya hanya diabaikan dan tidak dilakukan penanganan, hal ini dikhawatirkan akan berlanjut pada tahap yang lebih parah, yaitu depresi pada ibu nifas.

Suatu penelitian menyebutkan bahwa wanita pada masa nifas yang mengalami cemas atau depresi memiliki kecenderungan untuk melukai dirinya sendiri $(19,3 \%)$ dan sering memikirkan untuk melukai dirinya sendiri $(3,2 \%)$. Penelitian lain menyebutkan bahwa bunuh diri merupakan penyebab ketujuh kematian ibu dalam waktu 6 bulan setelah melahirkan sebesar 1,27 per 100.000 kematian ibu.

Masa nifas merupakan waktu yang penting bagi ibu dan bayi yang beresiko tinggi bagi ibu. Pada masa ini, selain ibu beresiko mengalami gangguan psikologis seperti kecemasan,ibu nifas juga dapat mengalami kematian (WHO,2017). Dimasa pandemi Covid-19 petugas kesehatan tidak dapat bertemu secara langsung dengan ibu nifas dan banyak orang lainnya dikarenakan harus melakukan physical distancing/social distancing untuk menghindari penularan Covid-19, sehingga petugas kesehatan menggunakan media modul untuk memberikan konseling dan pengetahuan kepada ibu nifas untuk mengurangi kecemasannya pada masa nifas dalam menyusui supaya tetap aman dan lancar.

Depresi Postpartum atau depresi pasca persalinan merupakan kondisi yang mungkin dialami oleh perempuan pada periode pascapersalinan. Tidak seorang pun yang mengira akan mengalami hal tersebut. Karena pada umumnya perempuan yang hamil, terlebih baru 
pertama kali, tentu sangat menantikan kehadiran bayinya. Depresi adalah salah satu penyakit gangguan mood. Sebanyak dua pertiga orang dengan depresi tidak menyadari bahwa mereka memiliki penyakit yang dapat disembuhkan sehingga tidak mencari pengobatan. Selain itu, kebodohan dan mispersepsi penyakit oleh masyarakat, termasuk penyedia kesehatan, sebagai suatu kelemahan pribadi atau kegagalan yang dapat menyebabkan stigmatisasi yang menyakitkan dan menghindari diagnosa sehingga banyak dari mereka yang terkena dampak.

\section{METODE}

Pengabdian kepada masyarakat dilaksanakan pada bulan Februari tahun 2020. Peserta adalah ibu nifas di wilayah kerja UPT Puskesmas Sumbul Pegagan Kabupaten Dairi berjumlah 24 orang. Tahapan pelaksanaan pengabdian kepada masyarakat melalui strategi pelaksanaan kegiatan pengabdian masyarakat ini dilaksanakan dengan langkah-langkah sebagai berikut:

1) Meminta izin untuk pelaksanaan kegiatan kepada UPT Puskemas Sumbul Pegagan

2) Persiapan dan penyusunan modul pencegahan covid-19 pada ibu nifas dan menyusui

3) Wawancara dan pengisian instrument

4) Metode yang diterapkan dalam kegiatan ini dengan melakukan pemberian informasi kesehatan dalam bentuk konseling untuk meningkatkan pengetahuan tentang pandemi covid-19, maka peserta diberikan edukasi yang berisi tentang pelaksanaan pelayanan kebidanan nmasa nifas saat COVID-19 melalui media modul dengan melakukan kunjungan ke rumah.

5) Melakukan follow up dua minggu setelah pelaksanaan kegiatan pengabdian masyarakat untuk monitoring peningkatan pengetahuan dan perubahan perilaku serta tingkat kecemasan ibu.

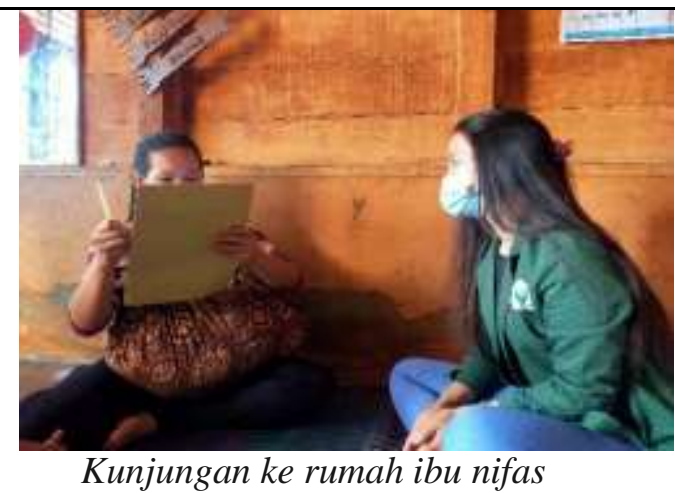

\section{HASIL DAN PEMBAHASAN}

Pemberian informasi mengenai pemberian pelayanan masa nifas saat covid-19 dan standar pelayanan asuhan kebidanan dan dokumentasi telah dilaksanakan tanpa ada kendala, dilaksanakan dengan durasi 2 jam 30 menit.

Berdasarkan hasil wawancara dan pengisian instrument menunjukkan mayoritas yang memiliki kecemasan dari beberapa tingkat kecemasan yang mempunyai tingkat kecemasan ringan yakni sebanyak 3 responden (12,3\%), sedang yakni sebanyak 4 responden $(16,4 \%)$, berat yakni sebanyak 4 responden $(16,4 \%)$ dan sangat berat yakni sebanyak 13 responden $(53,3 \%)$.

Diskusi dan tanya jawab peserta didapatkan bahwa ibu-ibu memahami dan mengetahui bagaimana cara mengatasi kecemasan saat pandemic covid-19. Setelah kegiatan pengabdian masyarakat ini berakhir, melakukan follow up dua minggu setelah pelaksanaan kegiatan kemudian peserta mengikuti pos-test. Hasil evaluasi tingkat pengetahuan peserta berdasarkan hasil pos-test menunjukkan adanya peningkatan yang signifikan, mayoritas yang memiliki kecemasan berdasarkan konseling dengan menggunakan modul sebagai media edukasi terhadap tingkat kecemasan yang mempunyai tingkat kecemasan ringan yakni sebanyak 6 responden $(24,6 \%)$, sedang yakni sebanyak 8 responden $(32,8 \%)$, berat yakni sebanyak 6 responden $(24,6 \%)$ dan sangat berat yakni sebanyak 4 responden $(16,4 \%)$. Hasil analisis uji $t$-test menunjukkan bahwa nilai $\mathrm{p}=0,000$ yang berarti kurang dari $\alpha=0,005$, maka dapat disimpulkan terdapat pengaruh konseling pada masa 
pandemi Covid-19 terhadap tingkat kecemasan ibu nifas di UPT Puskesmas Sumbul Kecamatan Sumbul Kabupaten Dairi Tahun 2020. Hal ini menjadi indikator adanya efektifnya pemberian modul tentang asuhan selama masa nifas dan menyusui yang telah dilakukan dalam kegiatan pengabdian masyarakat ini.

\section{KESIMPULAN}

Kegiatan pengabdian kepada masyarakat oleh tim pengabdi STIKes Mitra Husada Medan telah dapat meningkatkan pengetahuan tentang pencegahan covid-19 selama masa nifas dan menyusui dan menurunkan tingkat kecemasan peserta. Hasil evaluasi tingkat pengetahuan peserta berdasarkan hasil pos-test menunjukkan adanya peningkatan yang signifikan. Hal tersebut mengindikasikan efektifnya pemberian konseling menggunakan modul sebagai media edukasi terhadap tingkat kecemasan ibu nifas pada masa Pandemi covid-19. Saran selanjutnya Perlu adanya pengembangkan terhadap update ilmu -ilmu terbaru tentang info -info seputar covid-19 yang masih perlu banyak untuk disosialisasikan.

\section{UCAPAN TERIMAKASIH}

Terimakasih kami ucapkan kepada STIKes Mitra Husada Medan dan UPT Puskesmas Sumbul Kabupaten Dairi untuk terselenggaranya Pengabdian kepada masyarakat ini.

\section{REFERENSI}

Kementrian Kesehatan Republik Indonesia. (2020). Pedoman kesiapsiagaan menghadapi infeksi novel coronavirus (2019-ncov). Jakarta: Kemenkes RI.

Kementrian Kesehatan Republik Indonesia. (2020). Pedoman bagi ibu hamil, nifas dan bayi aru lahir di era pandemi Covid-19. Jakarta: Kemenkes RI.

Perkumpulan Obstetri dan Ginekologi Indonesia. (2020). Rekomendasi Penanganan Infeksi Virus Corona (COVID-19) Pada Maternal (Hamil, Bersalin Dan Nifas).

POGI. (2020). Penanganan Infeksi Virus Corona (Covid-19) Pada Maternal (Hamil, Bersalin Dan Nifas).

Setiana, A. 2019. Asuhan Kebidanan Pada Ibu Nifas. Jakarta : Guepedia. childbirth and breastfeeding. https://www.who.int/news-room/g-a-detail/g-a-oncovid-19pregnancy-childbirth-and breastfeeding 